\title{
INVESTIGATION OF THE CONSERVATION OF VITAMINS AND MICROELEMENTS DURING STORAGE IN BOILED- SMOKED SAUSAGES WITH ENRICHED LEGUMINOUS FLOUR
}

\author{
Yana Biletska \\ monika3384@ukr.net \\ Taisia Ryzhkova \\ Department of processing technology, standardization and technical service \\ Kharkiv State Zooveterinary Academy \\ 1 Akademichna str., Mala Danylivka, Dergachivsky district, Kharkiv region, Ukraine, 62341 \\ rugkova.ua@gmail.com
}

\author{
Anna Perepelytsia ${ }^{1}$ \\ irtb@karazin.ua \\ Andrii Husliev ${ }^{1}$ \\ guslev@karazin.ua
}

${ }^{1}$ Department of international e-commerce and hotel and restaurant business

V. N. Karazin Kharkiv National University

4 Svobody sq., Kharkiv, Ukraine, 61000

\begin{abstract}
There has been studied the conservation of vitamins and microelements in boiled-smoked sausages, using enriched leguminous flour. The research object is boiled-smoked sausages, in which recipes there were used sprout flour of soya and nut that are carriers of vitamins A, E, C, B6, B9, B12 and microelements, including iodine and selenium, as an enriching ingredient. One of problems for today is an increase of the population with endocrine disorders. It is possible to prevent this problem by timely prophylaxis as consumption of products with iodine. Modern studies in molecular pharmacology have proved that for assimilating iodine by the organism, the "presence" of other nutrients, intensifying its assimilability and being its synergists is needed. The method of inversion voltamperometry and the one of high-effective liquid chromatography were used in the study.

It has been established, that sausage products contain in their composition after 30 days of storage vitamins: $\mathrm{A}-0.4$; $\mathrm{E}-0.3$; C - 17; B6 - 0.32; B9 - 0.4; B12 - 0.03, mg/100 g. And microelements: Fe - 5.0; mg - 340, Z - 8.5, Cu - 0.95; Se - 0,026; I $-0,025, \mathrm{mg} / 100 \mathrm{~g}$. That satisfies: 50; 150; 30,9; 150; 200; $100 \%$ of the daily need in vitamins A; E; C; B6; B9; B12, respectively and $50 ; 97 ; 85 ; 95 ; 37 ; 37.5 \%$ of the daily need in microelements Fe; $\mathrm{mg} ; \mathrm{Z} ; \mathrm{Cu}$; Se; I, respectively. Comparing with a control recipe, enriched products have the increased content of nutrients - iodine synergists that provide essential advantages, "covering" deficiency conditions in other substances, needed for iodine assimilation. Let's assume that it will be an effective prophylaxis for persons with iodinedeficiency diseases.
\end{abstract}

Keywords: vitamins, microelements, iodine, selenium, sausages, iodine deficiency, storage.

DOI: $10.21303 / 2504-5695.2020 .001320$

\section{Introduction}

Realization of the European program "Health for all in XXI century" needs to provide the population of the planet with full-value nutrition. There appears a necessity to search innovative approaches to development of new food products that are carriers of vitamins and microelements. Iodine is an essential microelement, necessary for synthesis of thyroid hormones. Iodine deficiency is considered throughout the world as the most spread cause of fetus' nervous system development disorders, endocrine ones that may be prevented by timely prophylaxis by food products, containing iodine $[1,2]$. Consumption of enriched products doesn't guarantee supply of the correspondent amount of the nutrient, which carrier is an enriching ingredient, to the human organism. Studies [3, 4] have demonstrated that at prophylaxis and treatment of iodine-deficiency conditions it is necessary to pay attention to the content and conservation of other micronutrients that are 
synergists of iodine and intensify its assimilation. It is known $[5,6]$, that most vitamins and microelements are rather unstable during storage.

In this connection it is topical in the scientific-practical aspect to determine the content of vitamins and microelements during storage in food products, developed for consuming by the population under iodine-deficiency conditions.

\section{Analysis of literary data and statement of the problem}

Analyzing works of scientists, studying the use of sprouted leguminous grains in sausages production, it has been established, that they sprout grain legumes in water solutions. Work [7] present results of experiments, studying characteristics of forcemeats of semi-smoked sausages, using flour with barley grains and malt of leguminous grains. The effectiveness of their use for stabilizing autolytic processes and increasing the buffer capacity of meat-vegetable stuffing has been proved. It has been determined, that the optimal amount of introducing sprouted barley flour for producing semi-smoked sausages is $2 . . .3 \%$.

Studies [8] have proved the expedience of replacing meat raw materials for flour of lentil grains, sprouted in the water solution, at producing sausages. It has been established, that the replacement of meat raw materials for lentil flour in amount 1.5 and $2 \mathrm{~kg}$ for $100 \mathrm{~kg}$ of meat raw materials is expedient and raises the energetic value of new types of sausages by 10.5 and $16.3 \mathrm{kcal}$ for $100 \mathrm{~g}$ of the product, comparing with a control sample. Sausages with sprouted lentil flour contain more indispensable amino acids than ones with not sprouted lentil flour and control.

[9] studies a possibility to produce flour of grains of the leguminous crop mash (Phaseolus aureus). There has been established the change of the amino acid composition to the increase of indispensable amino acids, namely, aminosuccinic, noted the high hydrophilicity of flour in forcemeats. There have been determined optimal concentrations (10\% of the meat raw material mass) at producing boiled-smoked sausages.

But all offered technologies are not a carrier of microelements. Special attention must be paid to iodine and selenium deficiency, which lack is observed in $17 \%$ of the world population [10]. For enriching leguminous grains with microelements, the expedience of using mineral salts has been scientifically substantiated [11].

In works [12] lupine grains were sprouted in the potassium iodate solution $\left(\mathrm{KIO}_{3}\right)$. The production technology includes washing of grains, their turn-by-turn air-water soaking, sprouting, drying, grinding. Flour, obtained by the developed technology, is an iodine carrier $(30 \mathrm{mcg} / 100 \mathrm{~g})$ and has the increased content of protein. Scientists have proved [13] the expedience of using sodium hydroselenite $\left(\mathrm{NaHSeO}_{3}\right)$ at sprouting soya grains. The method includes washing of grains, their turn-by-turn air-water soaking, sprouting and drying, and differs by the fact that grains are soaked in the selenium solution with a concentration from 1.7 to $3.2 \mathrm{mcg} / \mathrm{ml}$ of the selenium content. The content of selenium in flour reaches $15-28 \mathrm{mcg} / 100 \mathrm{~g}$. The use of sprouted flour at producing sausages is regulated at the SSU level and must be no more $10 \%$ of the product mass [14]. That is why the use of aforementioned technologies is not expedient because of unessential \% of satisfying the daily need in the enriching microelement.

Studies $[15,16]$ on the development of flour of soya beans, sprouted in the potassium iodide solution $\left(\mathrm{KIO}_{3}\right)$ and flour of nut beans, sprouted in the sodium hydroselenite solution $\left(\mathrm{NaHSeO}_{3}\right)$ that are carriers of 50 and $52 \mathrm{mcg} / 100 \mathrm{~g}$ of iodine and selenium, respectively are being conducted. Sprouted leguminous grains are also carriers of vitamins A, E, C, B6, B9, B12. Work [17] considers the expedience of using developed leguminous flour at producing boiled-smoked sausages. But unsolved questions are connected with the conservation of microelements and vitamins during storage of ready products. As far as there are no enough data about solving these questions, it is necessary to deepen and widen studies in this direction.

\section{Research aim and task}

The research aim is to study the conservation of vitamins and microelements during storage in sausages with enriched leguminous flour. 
The following tasks were set for attaining this aim:

- to determine the conservation of vitamins in sausages during storage;

- to determine the conservation of microelements in sausages during storage.

4. Materials and methods for studying production of sausages, enriched with leguminous flour Raw materials, used for producing enriched sausages: "Soya flour, enriched with iodine" TC U 10.6-02071205-001:2019 is a carrier of $50 \mathrm{mcg}$ of iodine in $100 \mathrm{~g}$ of flour. "Nut flour, enriched with selenium" TC U 10.6-02071205-002:2019" is a carrier of $52 \mathrm{mcg}$ of selenium in 100 grams of flour.

A control sample of boiled-smoked sausage was produced by classic recipe [18] according to SSU 4591: 2006 "Boiled-smoked sausages".

An experimental sample of boiled-smoked sausage was produced, using $10 \%$ of enriched leguminous flour in ratio (1:1) at the expanse of decreasing meat raw materials in equal shares, namely beef, pork and lard.

All samples of sausage products were packed in clean dry, without side smells, boxes of cardboard and stored at the relative humidity from $75 \%$ to $78 \%$.

A storage term was determined, based on SSU 4591:2006 "Boiled-smoked sausages" (point 10.2.3 "Shelf life of sausages") at temperature $4^{\circ} \mathrm{C}$ during 30 days.

There was used a viscous-reinforced barrier protective film with lamination (produced by LTD “MNS” group, Kharkiv, Ukraine) [19], that must provide an unessential loss level of moisture and enriching substances [20]. Research results were statistically processed by Exel.

\section{1. Methods, used at studying the vitamins content}

Vitamins were determined by the method of high-effective liquid chromatography, using the chromatograph "Lumachrom" (Russia, Saint-Petersburg) and detectors: spectrophotometric - 3220; fluorometric - 2410. The content of vitamin A was determined by the number of pigments of carotenoids. The studies were conducted at the base of the research institution "Biotech" (Ukraine, Kyiv).

\section{2. Methods, used at studying the microelements content}

The mass share content of microelements was determined by the method of "Inversion volamerometry" by the voltamperometric analyzer "AVA", completed by indicator electrodes for determining mass shares of different microelements [18].

\section{Results of studying the content of vitamins and microelements at storage in sausages, en- riched with leguminous flour}

Table 1 presents the results of studying the conservation of vitamins and microelements at storage in sausages, enriched with leguminous flour.

It has been studied, that the use of enriched leguminous flour at producing boiled-smoked sausages increases the content of vitamins, namely vitamin A from 0.2 to $0.4 \mathrm{mg} / 100 \mathrm{~g}$, and vitamin E from 2.75 to $0.4 \mathrm{mg} / 100 \mathrm{~g}$ of the product. There is also observed the increase of B group vitamins: B6 (from 0.1 to $0.32 \mathrm{mg} / 100 \mathrm{~g}$ ); B9 (from 0.15 to $0.4 \mathrm{mg} / 100 \mathrm{~g}$ ); B12 (from 0.01 to $0.03 \mathrm{mg} / 100 \mathrm{~g}$ ). The content of mineral substances in the produced boiled-smoked sausages by such microelements as $\mathrm{Fe}, \mathrm{mg}, \mathrm{Z}, \mathrm{Cu}$ remained almost stable and correspondent to the control sample. The changes were observed by selenium (from 0,005 to $0,026 \mathrm{mcg} / 100 \mathrm{~g}$ ) and iodine (in the control sample it was $0,025 \mathrm{mg} / 100 \mathrm{~g}$ ). The increase of these indices is explained by their content in the enriched four. Analyzing the content of vitamins in the sausages during storage, it has been established, that at storage during 30 days losses of vitamins $\mathrm{A}, \mathrm{E}, \mathrm{C}$ by $20 \ldots 70 \%$ of the initial content are fixed in both experimental and control samples. The content of B group vitamins B (B6; B9; and B12) during storage in the experimental samples didn't undergo essential changes, and at the end of the studied term it was $030 ; 0.4$ and $0.03 \mathrm{mg} / 100 \mathrm{~g}$, respectively. It is known, that the enrichment of products with vitamins B6, B9, B12 together with vitamin E allows to minimize losses of B group vitamins with vitamin E loss up to $20 \%$ [20]. Studying 
the content of microelements in the sausages during storage, it has been established, that during 30 days iron losses are observed by $1 \mathrm{mg}$ in $100 \mathrm{~g}$ of the product - in the control sample, and by $2 \mathrm{mg} / 100 \mathrm{~g}$ - in the experimental one. Storage of the boiled-smoked sausages during 30 days didn't decrease the content of iodine, selenium, magnesium, zinc, cooper in the studied samples essentially, so let's assume that the studied microelements are organically connected with vegetable proteins, amino acids of leguminous grains.

Table 1

The study of the content of vitamins and microelements at storage in sausages, enriched with leguminous flour

\begin{tabular}{|c|c|c|c|c|c|c|c|c|c|c|c|c|}
\hline \multirow{2}{*}{ Parameter } & \multicolumn{6}{|c|}{ Vitamins, mg } & \multicolumn{6}{|c|}{ Microelements, mg } \\
\hline & $\mathbf{A}$ & $\mathbf{E}$ & $\mathrm{C}$ & B6 & B9 & B12 & $\mathrm{Fe}$ & Mg & $\mathbf{Z}$ & $\mathrm{Cu}$ & Se & I \\
\hline Daily need & 0.8 & 2.0 & 55.0 & 0.2 & 0.2 & 0.03 & 10.0 & 350 & 10 & 0.1 & 0.07 & 0.15 \\
\hline \multicolumn{13}{|c|}{ Content of vitamins and microelements in soya flour, enriched by iodine } \\
\hline in $50 \mathrm{~g}$ & 0.2 & 2.1 & 8.0 & 0.15 & 0.2 & 0.015 & 4.5 & 195 & 4.0 & 0.45 & 0,005 & 0,025 \\
\hline \multicolumn{13}{|c|}{ Content of vitamins and microelements in nut flour, enriched by selenium } \\
\hline in $50 \mathrm{~g}$ & 0.2 & 1.9 & 9.0 & 0.17 & 0.2 & 0.015 & 3.5 & 160 & 4.5 & 0.5 & 0,026 & 0,010 \\
\hline \multicolumn{13}{|c|}{ Boiled-smoked sausage } \\
\hline Control & 0.2 & 2.75 & 17.5 & 0.01 & 0.15 & 0.01 & 8.0 & 350 & 4.0 & 0.45 & 0,005 & traces \\
\hline Experiment & 0.4 & 4.0 & 17 & 0.32 & 0.4 & 0.03 & 8.0 & 350 & 8.5 & 0.95 & 0,026 & 0,025 \\
\hline \multicolumn{13}{|c|}{ At storage of the ready product (at $5^{\text {th }}$ day) } \\
\hline Control & 0.2 & 2.3 & 10.1 & 0.01 & 0.15 & 0.01 & 6.0 & 345 & 4.0 & 0.45 & 0,005 & traces \\
\hline Experiment & 0.4 & 3.9 & 12.5 & 0.32 & 0.4 & 0.03 & 7.0 & 345 & 8.5 & 0.95 & 0,026 & 0,025 \\
\hline \multicolumn{13}{|c|}{ At storage of the ready product (at $15^{\text {th }}$ day) } \\
\hline Control & 0.15 & 1.9 & 17.5 & 0.01 & 0.15 & 0.01 & 6.0 & 340 & 4.0 & 0.45 & 0,005 & traces \\
\hline Experiment & 0.38 & 3.2 & 17 & 0.32 & 0.4 & 0.03 & 6.0 & 345 & 8.5 & 0.95 & 0,026 & 0,025 \\
\hline \multicolumn{13}{|c|}{ At storage of the ready product (at $30^{\text {th }}$ day) } \\
\hline Control & 0.2 & 1.2 & 17.5 & 0.01 & 0.15 & 0.01 & 5.0 & 335 & 4.0 & 0.45 & 0,005 & traces \\
\hline Experiment & 0.4 & 3.0 & 17 & 0.30 & 0.4 & 0.03 & 5.0 & 340 & 8.5 & 0.95 & 0,026 & 0,025 \\
\hline
\end{tabular}

Note: Indices are given for a healthy adult with a middle labor intensity [19]

\section{Conclusions}

The content of vitamins in the sausages during storage has been determined. It has been established, that sausage products contain in their composition after 30 days of storage vitamins: $\mathrm{A}-0.4 ; \mathrm{E}-0.3 ; \mathrm{C}-17$; B6 - 0.32; B9 - 0.4; B12 - 0.03, mg/100 g. That satisfies: 50; 150; 30.9; 150; $200 ; 100 \%$ of the daily need in vitamins A; E; C; B6; B9; B12, respectively.

The content of microelements in the sausages during storage has been determined. It has been established, that the new sausage products contain in their composition after 30 days of storage: $\mathrm{Fe}-5.0 ; \mathrm{mg}-340, \mathrm{Z}-8.5, \mathrm{Cu}-0.95 ; \mathrm{Se}-0.026$; I - 0.025, mg/100 g. That satisfies: 50; 97; $85 ; 95 ; 37 ; 37.5 \%$ of the daily need in microelements $\mathrm{Fe}$; $\mathrm{mg} ; \mathrm{Z}$; $\mathrm{Cu}$; Se; I, respectively.

Comparing with a control recipe, enriched products have the increased content of nutrients iodine synergists that provide essential advantages, "covering" deficiency conditions in other substances, needed for iodine assimilation. Let's assume that the developed recipe will be an effective prophylaxis for persons with iodine-deficiency diseases. 


\section{References}

[1] Ryzhkova, T., Bondarenko, T., Dyukareva, G., Biletskaya, Y. (2017). Development of a technology with an iodine-containing additive to produce kefir from goat milk. Eastern-European Journal of Enterprise Technologies, 3 (11 (87)), 37-44. doi: https:// doi.org/10.15587/1729-4061.2017.103824

[2] Lynnyk, S. O. (2013). Stratehiya VOOZ «Zdorovia-2020" yak zasib pryskorennia prohresu v dosiahnenni maksymalnoho potentsialu u sferi okhorony zdorovia naselennia. Publichne upravlinnia: teoriya ta praktyka, 1, 191-195. Available at: http:// nbuv.gov.ua/UJRN/Pubupr_2013_1_32

[3] Peresichnyi, M. I., Fedorova, D. V., Palamarek, K. V. (2013). Proektuvannia bilkovo-roslynnykh past iz pidvyshchenym umistom yodu. Obladnannia ta tekhnolohiyi kharchovykh vyrobnytstv, 30, 135-143. Available at: http://journals.uran.ua/index. php/2079-4827/article/download/22232/19750

[4] Gromova, O. A., Torshin, I. Yu., Kosheleva, N. G. (2011). Molekulyarnye sinergisty yoda: novye podhody k effektivnoy profilaktike i terapii yod-defitsitnyh zabolevaniy u beremennyh. RMZh, 1, 51. Available at: https://www.rmj.ru/articles/ ginekologiya/Molekulyarnye_sinergisty_yoda_novye_podhody_k_effektivnoy_profilaktike_i_terapii_yoddeficitnyh_ zabolevaniy_u_beremennyh/

[5] Humeniuk, O. L. (2013). Kharchova khimiya. Laboratornyi praktykum. Chernihiv: ChDTU, 151. Available at: https://cpo.stu.cn.ua/ Oksana/harch_himia_lab_prakt/

[6] Makarynska, A. V., Yehorov, B. V. (2009). Vid vyrobnytstva stabilnykh preparativ biolohichno aktyvnykh rechovyn do vyrobnytstva stabilnykh premiksiv (chastyna 1). Zernovi produkty i kombikormy, 4 (36), 33-41.

[7] Pasichnyi, V. M., Moroz, O. O., Zakhandrevych, O. A. (2008). Doslidzhennia kharakterystyk miasnykh farshiv dlia vyrobnytstva napivkopchenykh kovbas z vykorystanniam solodiv zlakovykh kultur. Naukovyi visnyk LNUVMBT imeni S. Z. Gzhytskoho, 10 (3 (38)), 261-264.

[8] Paska, M., Markovych, I., Simonov, R. (2014). Functional technological indicators smoked sausages with partial replacement of meat raw lentil flour. Naukovyi visnyk Lvivskoho natsionalnoho universytetu veterynarnoi medytsyny ta biotekhnolohiyi im. Gzhytskoho, 16 (3 (60)), 119-128.

[9] Kazymov, S. A., Prudnikova, T. N. (2012). Germination influence on amino acids composition of mash beans. Izvestiya vysshih uchebnyh zavedeniy. Pishchevaya tehnologiya, 5-6, 25-26.

[10] Pankiv, V. I. (2014). Problem of combined selenium and iodine deficiency in the development of thyroid pathology. Mizhnarodnyi endokrynolohichnyi zhurnal, 5, 75-80. Available at: http://nbuv.gov.ua/UJRN/Mezh_2014_5_16

[11] Biletska, Ya. O., Chuiko, A. M., Sidorov, V. I., Danko, N. I., Huslev, A. P., Babenko, V. A. (2019). Pat. No. 139154 UA. Sposib oderzhannia solodu. No. u201905186; declareted: 27.05.2019; published: 26.12.2019, Bul. No. 24.

[12] Arsenieva, L. Yu., Antoniuk, M. M., Herasymenko, L. O. (2003). Pat. No. 62459 UA. Composition for enrichment of bread micronutrient proportion. No. 2003032649; declareted: 27.03.2003; published: 15.12.2003; Bul. No. 12.

[13] Stabnikova, O. V., Khivrych, B. I., Antoniuk, M. M. (2001). Selenovmisni dobavky roslynnoho pokhodzhennia yak perspektyvnyi napriam profilaktyky nestachi selenu. 67-a naukova konferentsiya studentiv, aspirantiv i molodykh vchenykh. Kyiv: UDUKhT, 74.

[14] DSTU 4591:2006. Kovbasy vareno-kopcheni. Zahalni tekhnichni umovy. Z popravkoiu (2006). Kyiv. Available at: http:// online.budstandart.com/ua/catalog/doc-page?id_doc=83086

[15] Biletska, Y., Plotnikova, R., Skyrda, O., Bakirov, M., Iurchenko, S., Botshtein, B. (2020). Devising a technology for making flour from chickpea enriched with selenium. Eastern-European Journal of Enterprise Technologies, 1 (11 (103)), 50-58. doi: https://doi.org/10.15587/1729-4061.2020.193515

[16] Biletska, Y., Plotnikova, R., Danko, N., Bakirov, M., Chuiko, M., Perepelytsia, A. (2019). Substantiation of the expediency to use iodine-enriched soya flour in the production of bread for special dietary consumption. Eastern-European Journal of Enterprise Technologies, 5 (11 (101)), 48-55. doi: https://doi.org/10.15587/1729-4061.2019.179809

[17] Biletska, Y., Perepelytsia, A., Bilovska, O. (2020). Determination of consumer preferences of different groups of food. EUREKA: Social and Humanities, 1, 23-26. doi: https://doi.org/10.21303/2504-5571.2020.001136

[18] Klymenko, M. M. (2006). Vyrobnytstvo vareno-kopchenykh kovbas. Tekhnolohiya miasa ta miasnykh produktiv. Kyiv: Vyshcha osvita. Available at: https://buklib.net/books/34941/

[19] Poliamidnaya kolbasnaya obolochka, belkovaya kolbasnaya obolochka. Available at: https://ua.all.biz/poliamidnaya-kolbasnayaobolochka-belkovaya-g3838405

[20] Kharchovi obolonky dlia kovbasnykh vyrobiv. Klasyfikatsiya kovbasnoi obolonky za vydamy. Available at: https://kare18.ru/ uk/testo-presnoe/pishchevye-obolochki-dlya-kolbasnyh-izdelii-klassifikaciya-kolbasnoi/ 